\title{
The Impact of Energy Source on the Life-Cycle Assessment of Power-to-Liquid Fuels
}

\author{
Maha Alhyari ${ }^{1 *}$, Ahmed Al-Salaymeh ${ }^{1}$, Mahmoud Irshidat ${ }^{1}$, \\ Martin Kaltschmitt ${ }^{2}$, Ulf Neuling ${ }^{2}$ \\ 1 Mechanical Engineering Department, The University of Jordan, Amman 11942, Jordan \\ 2 Institute of Environmental Technology and Energy Economics, Hamburg University of Technology, Hamburg \\ 21073, Germany \\ * Corresponding author's e-mail: maha_hyari@yahoo.com
}

\begin{abstract}
Power-to-liquid (PtL) fuels are a promising technology and alternative to biofuels and conventional fuels. In this work, the environmental impact of PtL was investigated using life cycle assessment (LCA) in order to see how the energy source used in producing the PtL affects the environmental impacts of the fuel. The electrolysis cell used was solid oxide electrolysis cell, and the pathway of $\mathrm{CO}_{2}$ provision was biomass power plant. Four scenarios of energy sources were compared; the first scenario involved the electricity from German grid and heat from chemical industry, the second one was the electricity from Saudi Arabia grid and heat from chemical industry, the third one concerned the electricity from wind turbine and heat from evacuated tube collector, and the fourth scenario was the electricity from photovoltaic and heat from evacuated tube collector. The result of the life cycle assessment showed that the PtL fuels have environmental benefits over the fossil reference only in the third and fourth scenarios where renewable electricity was used.
\end{abstract}

Keywords: power-to-liquid, life cycle assessment.

\section{INTRODUCTION}

Power-to-liquid (PtL) fuels are similar to hydrocarbons as the fossil-derived synthetic fuel and it can be produced by the conversion of carbon dioxide and water using a specific energy source. There are two pathways for the production of PtL; Fischer-Tropsch synthesis and Methanol-Route.

There are two types of energy used in the production of PtL, electricity and heat. Electricity is used in the production of hydrogen from the electrolysis cell, in the $\mathrm{CO}_{2}$ provision and in the Fischer-Tropsch itself. The process that needs the most electricity is the electrolysis of water. Heat is used in the $\mathrm{CO}_{2}$ provision and that is due to the use of SOEC electrolysis cell, since it's a high temperature electrolysis cell, it uses the heat from the Fischer-Tropsch so an external heat source is necessary for the $\mathrm{CO}_{2}$ provision. The combination of SOEC and the $\mathrm{CO}_{2}$ was used in this work because it was found to have the best Life Cycle Assessment results among all other possible combination in the previous work mentioned earlier.

In this work, different types of energy sources were used in order to study the impact of an energy source on the life cycle assessment of PtL, two types of renewable energy sources versus two types of non-renewable sources.

This paper aims to achieve the followings:

- Assessment of environmental impact categories: Global Warming Potential (GWP), Acidification and Cumulative Energy Demand. 
- Study the impact of the energy source used in the production of PtL on the environmental impact categories mentioned above.

- Comparison between GWP of PtL against a fossil reference.

\section{Literature review}

Parra, et al. [2017], applied techno-economic and life cycle assessment in order to define the key performance indicators on power to gas systems generating hydrogen or methane. They concluded that only the use of renewable electricity for electrolysis leads to environmental benefits for $\mathrm{P} 2 \mathrm{G}$ comparing to traditional gas production.

Schmidt et al. [2016], studied the concept of producing renewable jet fuel by using renewable electricity, the so-called Power-to-Liquids. The PtL production pathways and the capability of the obtained jet fuel were explained and their performances were discussed in terms of various effects such as greenhouse gas emissions, energy efficiencies, land requirements and water demand.

Mignard and Pritchard [2006], compared the energy efficiency of the three liquid fuels that could be easily manufactured from hydrogen and $\mathrm{CO}_{2}$, including: methanol, gasoline and mixed alcohols.

Zhang, et al. [2017], investigated the environmental performance of $\mathrm{P} 2 \mathrm{G}$ by using life cycle assessment (LCA). The results showed that P2G can reduce the Greenhouse Gas (GHG) emissions compared to traditional gas production technologies but it relies on the electricity supply and $\mathrm{CO}_{2}$ source.

Varone and Ferrari [2015], discussed the possible contribution of excess renewable electricity sideways with power-to-gas (PtG) and power-to-liquid (PtL) schemes in the 2050 German energy system, and that is by modeling an increase in installed renewable power. Different scenarios were taken into account and compared the results were used in an economic assessment of the cost for a presumptive power-to-liquid plant.

Larson [2006], reviewed the literature of the published life cycle analyses of liquid biofuels, focusing on the impacts of such fuels on the greenhouse gases emissions. Both traditional liquid biofuels such as biodiesel and future liquid biofuels such as Fischer-Tropsch were included.
A wide range in energy balance and greenhouse gas emission effects amongst different liquid biofuels and even for the same fuel was found, in addition to lack of studies on assessing the greenhouse gas emissions per unit of land area.

Sternberg and Bardow [2016], identified the conditions in which power-to-gas is environmentally beneficial. These conditions were stated as environmental thresholds for electricity supply which were taken from a comparative life cycle assessment of power-to-gas to fossilbased processes. Power to synthetic natural gas (SNG) and power to syngas were both analyzed; the pathways for the production of syngas are reverse water gas shift and dry reforming of methane. It was found that the syngas production by dry reforming of methane had the most environmental benefits and that both syngas pathways lead to larger benefits than SNG.

Iribarren, et al. [2013], studied the LCA for the coproduction of fuels and electricity from bio syngas feedstock via Fischer-Tropsch synthesis. It was found that the bio syngas production was the main source of impact with much higher contribution than the other processes like the waste treatment or catalysts.

Jungbluth, et al. [2008], studied the life cycle assessment of biomass-to-liquid (BtL) fuels; a complete life cycle was explored for the transportation of one person over one kilometer. The results showed that the emissions of greenhouse gases could be reduced by $28 \%$ to $69 \%$ with the BTL using forest wood or straw.

\section{METHODOLOGY}

The life cycle assessment (LCA) assesses the environmental impacts associated with all stages of a product's life, from the production of rawmaterial and passing through the manufacture and distribution till the end use and disposal. The process-based LCA was carried out in this work, OpenLCA version 1.6.3 was used as LCA software and version 3.1 of the ecoinvent database as source of background Life Cycle Inventory (LCI) data.

The impact methods that were applied are CML 2001 and cumulative energy demand, whereas the Impact categories that were investigated include:

- Climate change - GWP100.

- Acidification - average Europe / Generic.

- Cumulative energy demand. 
The chosen electrolysis cell is SOEC since it constitutes a high temperature electrolysis cell and thus has higher efficiency than the other electrolysis cells and the $\mathrm{CO}_{2}$ provision is from the flue gas of a biomass power plant since this combination was shown to be better than any other in a previous work. Different sources of energy were compared with each other in order to see the impact of the energy source has on the life cycle assessment of power to liquid fuels, the four scenarios of energy sources that were compared as follows:

- The first scenario is electricity from the German Production mix and heat from chemical industry.

- The second scenario is electricity from the Saudi Arabia grid and heat from chemical industry

- The third scenario is electricity from wind turbine and heat from evacuated tube collector in Germany.

- The fourth scenario is electricity from photovoltaic and heat from evacuated tube collector in Germany.

The input data for the electrolysis cell and the $\mathrm{CO}_{2}$ provision and the Fischer-Tropsch was taken from previous work of graduation project work from TUHH [Odenwald, 2017] and it is shown in the Table 1.

The process that has the highest electricity need is the electrolysis of water, followed by FischerTropsch process and finally the $\mathrm{CO}_{2}$ provision. The external heat is needed for the $\mathrm{CO}_{2}$ provision since the SOEC, being a high temperature electrolysis cell takes all the heat from the FischerTropsch process.

\section{RESULTS}

The results of the four impact categories for the all scenarios are as follows.

\section{Climate change}

Climate change shows the global warming potential the product has by giving the expected emission of greenhouse gases. Figure 1 shows the results for all the scenarios in gram $\mathrm{CO}_{2}$ equivalent per MJ of Diesel used along with the fossil reference. $\mathrm{CO}_{2}$ equivalent is a term that describes different greenhouse gases in common unit, so for any type of greenhouse gases like Methane or $\mathrm{Ni}$ trous Oxide, the term $\mathrm{CO}_{2}$ equivalent signifies the amount of $\mathrm{CO}_{2}$ that would have been equivalent in global warming impact.

The climate change potential for the four scenarios ranges between 8.6-429 $\mathrm{g} \mathrm{CO}_{2}$-Eq./MJ of Diesel used. Having the lowest emissions in the case of wind turbine followed by PV followed by the German grid and finally the highest when taking electricity from the Saudi Arabia grid.

In comparison with the climate change of the fossil reference which is according EU RED $83.8 \mathrm{~g} \mathrm{CO}_{2} / \mathrm{MJ}$, the PtL fuels have environmental benefits over it only in the case of renewable energy while in the case of taking the electric-

Table 1. The input data in case of SOEC and $\mathrm{CO}_{2}$ from flue gas

\begin{tabular}{|c|c|c|c|}
\hline \multicolumn{4}{|c|}{ Electrolysis Cell } \\
\hline \multicolumn{2}{|c|}{ Inputs } & \multicolumn{2}{|c|}{ Output } \\
\hline Water (kg) & $322,642.60$ & Hydrogen (kg) & $36,103.18$ \\
\hline Electricity (kWh) & $1,160,703.52$ & Oxygen (kg) & $286,539.50$ \\
\hline \multicolumn{4}{|c|}{$\mathrm{CO}_{2}$ provision } \\
\hline \multicolumn{2}{|c|}{ Inputs } & \multicolumn{2}{|c|}{ Output } \\
\hline Electricity (kWh) & $59,787.15$ & $\mathrm{CO}_{2}(\mathrm{~kg})$ & $294,840.90$ \\
\hline External Heat (kWh) & $6,992.47$ & & \\
\hline \multicolumn{4}{|c|}{ FT Process } \\
\hline \multicolumn{2}{|c|}{ Inputs } & \multicolumn{2}{|c|}{ Output } \\
\hline Hydrogen $(\mathrm{kg})$ & $36,103.18$ & Wastewater (kg) & $207,235.20$ \\
\hline $\mathrm{CO} 2(\mathrm{~kg})$ & $294,840.90$ & Waste gas as $\mathrm{CO}_{2}$, biogenic $(\mathrm{kg})$ & $103,750.00$ \\
\hline \multirow[t]{3}{*}{ Electricity (kWh) } & $83,656.00$ & Naphtha $(\mathrm{kg})$ & $22,974.78$ \\
\hline & & Kerosene $(\mathrm{kg})$ & $33,688.71$ \\
\hline & & Diesel (kg) & $5,322.52$ \\
\hline
\end{tabular}


ity from German grid, the GHG is about $277 \mathrm{~g}$ $\mathrm{CO}_{2}$-Eq./MJ of Diesel used and that is due to the relatively high share of fossil electricity in the German grid. While taking the electricity from the Saudi Arabia grid, the GHG was higher, 429 $\mathrm{g} \mathrm{CO}_{2}$-Eq./MJ of Diesel used and that is because electricity generation in Saudi Arabia is entirely dependent on fossil fuels; mainly oil followed by natural gas and steam and since Jordan is somehow similar to Saudi Arabia in that it also depends on fossil fuels to generate electricity, the results are expected to be close.

In the fourth scenario where PV was used, the GHG emissions were higher than in the third scenario where wind was used and that is probably due to the fact that the ecoinvent database is related to year 2012 and since PV technology has developed greatly in the past couple of years, the results might be better if a newer database is used, also PV might have more GHG emissions than wind due to the materials that enter in its production.

As for the contribution of different processes to the emissions, as expected the electrolysis of water process also had the largest share of the emissions.

\section{Acidification}

The acidification potential gives an indication of the emissions of acidifying pollutants which are mainly $\mathrm{SO}_{2}, \mathrm{NOx}$, and $\mathrm{NH}_{3}$ by calculating the acid formation potential of them and setting them against a reference substance which is

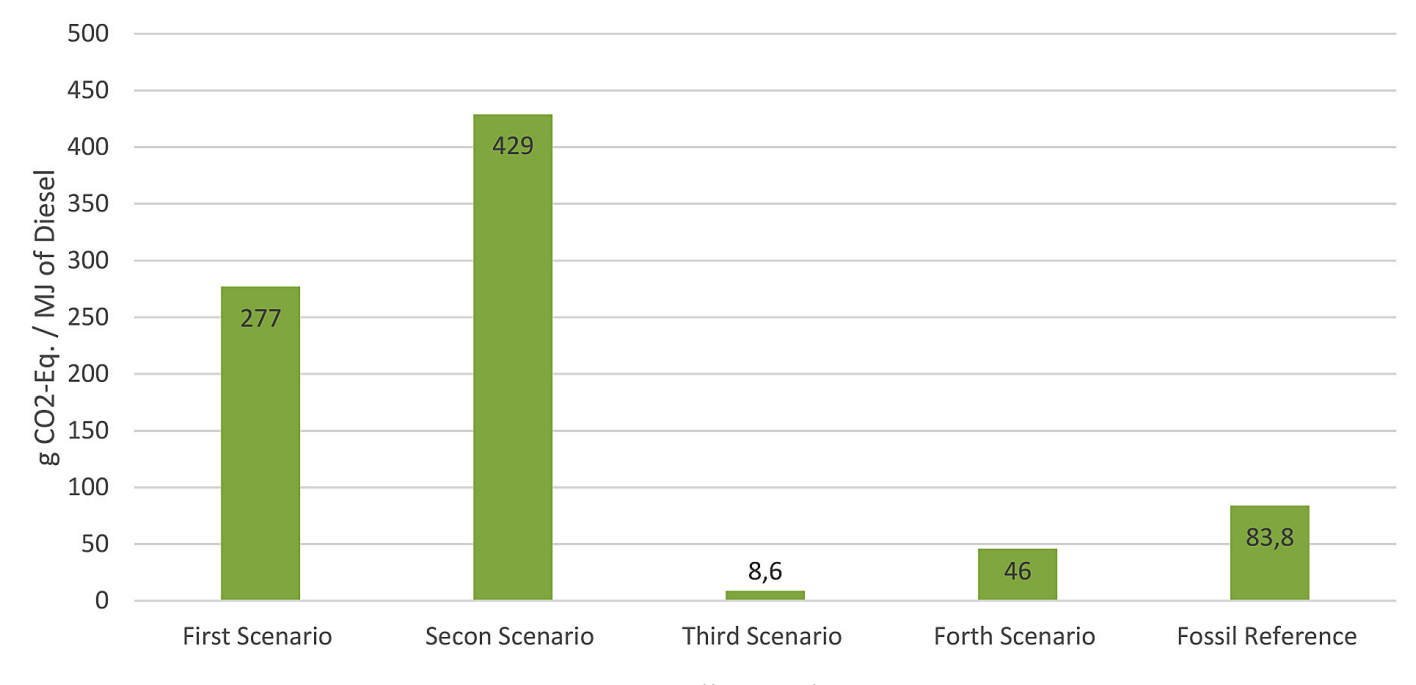

Figure 1. Climate change

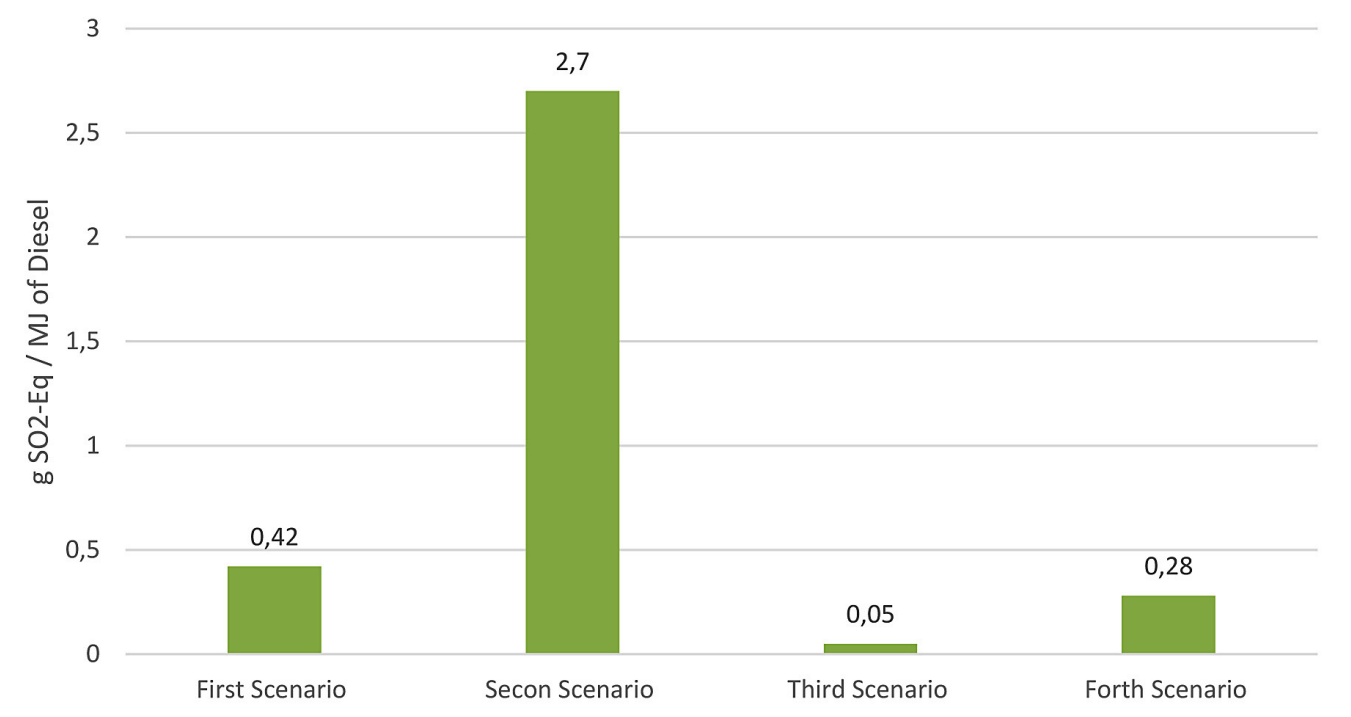

Figure 2. Acidification potential 


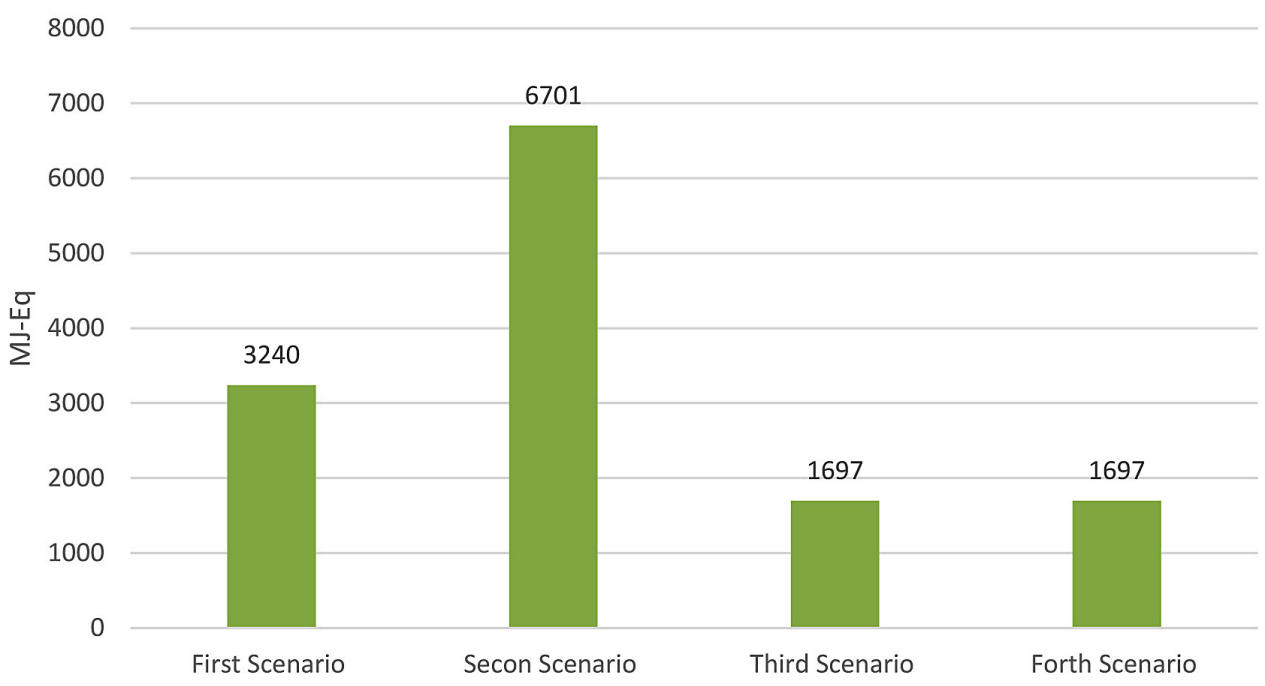

Figure 3. Cumulative energy demand

$\mathrm{SO}_{2}$. Figure 2 shows the acidification potential in gram of $\mathrm{SO}_{2}$ equivalent per MJ of Diesel used for the four scenarios.

The results ranged between 0.05-2.7 $\mathrm{g} \mathrm{SO}_{2}$-Eq./ MJ of Diesel used. Being the lowest in the third scenario and the highest in the second scenario.

The electrolysis of water process was the main source for the acidification potential in all combinations.

\section{Cumulative Energy Demand}

The cumulative energy demand is an important impact category that shows the energy demand for each scenario in MJ-Eq. It ranged between
$1697 \mathrm{MJ}-\mathrm{Eq}$ in the case of both third and fourth scenario and $6701 \mathrm{MJ}-\mathrm{Eq}$ in the second scenario amounting to $3240 \mathrm{MJ}-\mathrm{Eq}$ in the first scenario.

As for the contribution the different processes have to the climate change for the third scenario is shown in Figure 4.

The electrolysis of water has the greatest contribution followed by the electricity used in the Fischer-Tropsch process and the $\mathrm{CO}_{2}$ provision.

\section{CONCLUSION}

This work showed that the life cycle assessment of PtL fuels depends greatly on the energy source

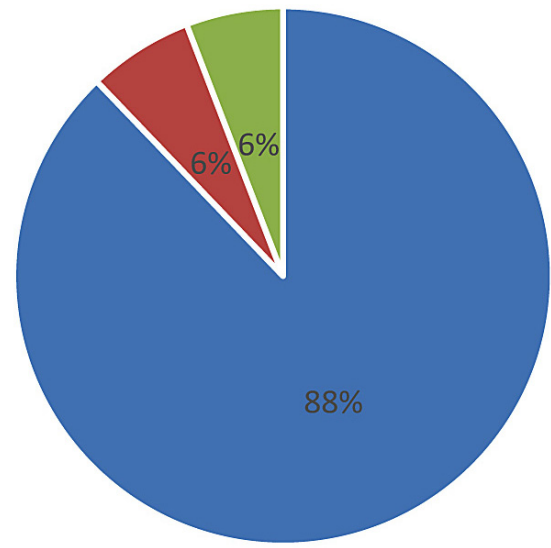

$$
\begin{aligned}
& \text { - Hydrogen from SOEC } \\
& \text { - electricity production for FT } \\
& \text { - } \mathrm{CO} 2 \text { from biomass power plants with heat }
\end{aligned}
$$

Figure 4. Contribution of processes in climate change - third scenario 
and that the PtL fuels have environmental benefits over the fossil fuels only when using renewable energy or taking the electricity from a grid that has high share of renewables. Future work can be made for investigating other sources of energy and to study other impact categories.

\section{REFERENCES}

1. Schmidt, P. Weindorf, W. Roth, A. Batteiger, V. and Riegel, F. 2016. Power-to-Liquids Potentials and Perspectives for the Future Supply of Renewable Aviation Fuel. German Environment Agency.

2. Mignard, D. and Pritchard, C. (2006), "Processes for the Synthesis of Liquid Fuels from $\mathrm{CO} 2$ and Marine Energy", Chemical Engineering Research and Design, 84, 828-836.

3. Parra, D. Zhang, X. Bauer, C. and Patel, M. 2017. An integrated techno-economic and life cycle environmental assessment of power-to-gas systems. Applied Energy, 193, 440-454.

4. Zhang, X. Bauer, C. Mutel, C. and Volkart, K. 2017. Life Cycle Assessment of Power-to-Gas: Approaches, system variations, and their environmen- tal implications. Applied Energy, 190, 326-338.

5. Varone, A. and Ferrari, M. 2015. Power to liquid and power to gas: An option for the German Energiewende. Renewable and Sustainable Energy Reviews, 45, 207-218.

6. Eric D. Larson 2006. A review of life-cycle analysis studies on liquid biofuel systems for the transport sector", Energy for Sustainable Development, 10, 109-126.

7. Sternberg, A. and Bardow, A. 2016. Life Cycle Assessment of Power-to-Gas: Syngas vs Methane. American Chemical Society, 4, 4156-4165.

8. Iribarren, D. Susmozas, A. and Dufour, J. 2013. Life-cycle assessment of Fischer-Tropsch products from biosyngas. Renewable Energy, 59, 229236.

9. Jungbluth, N. Büsser, S. Frischknecht, R. and Tuchschmid, M. 2008. Life Cycle Assessment of Biomass-to-Liquid Fuels. ESU-services $\mathrm{GmbH}$, Uster.

10. www.netl.doe.gov (National Energy Technology Laboratory).

11. Odenwald, P. 2017. Power-to-Liquid-Prozesse auf Basis der Fischer-Tropsch-Synthese - Simulation und Bewertung. Personal communication. 